Biogeosciences Discuss., https://doi.org/10.5194/bg-2019-33

Manuscript under review for journal Biogeosciences

Discussion started: 18 February 2019

(c) Author(s) 2019. CC BY 4.0 License.

1

2

3

4

6

7

8

9

\title{
Is the content and potential preservation of soil organic carbon reflected by cation exchange capacity? A case study in Swiss forest soils
}

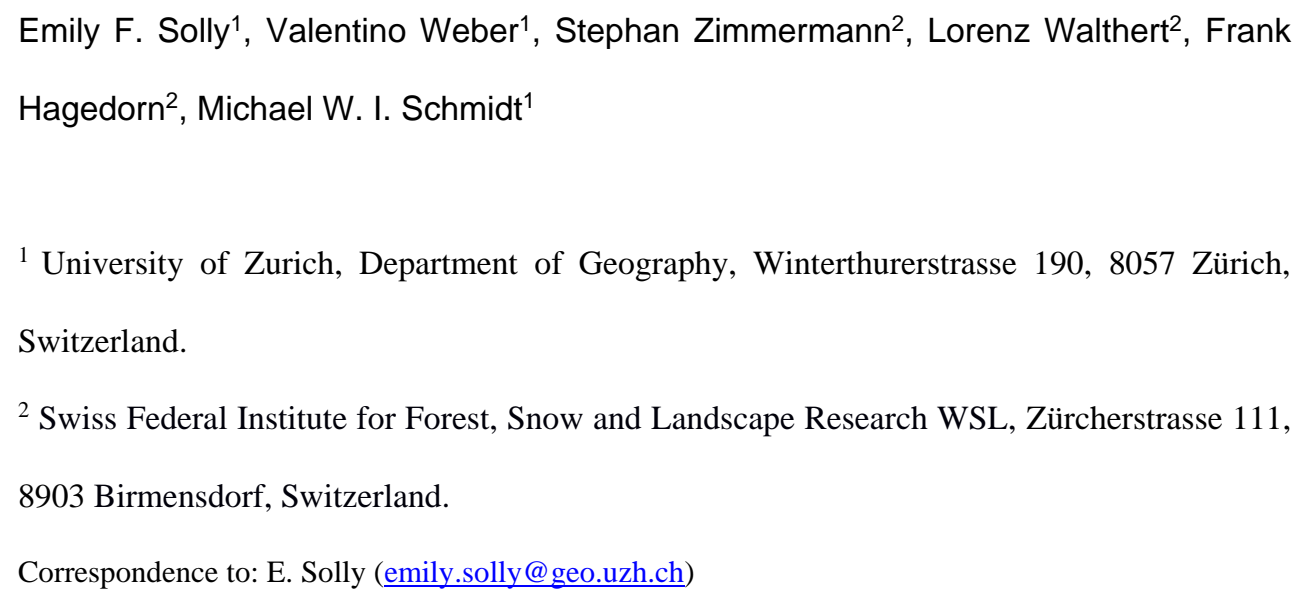

\section{Abstract}

The content of organic carbon (C) in soils is not stable, but depends on a number of environmental variables and biogeochemical processes that actively regulate its balance. An improved identification of the environmental variables that can be used as predictors of soil organic $\mathrm{C}$ (SOC) content is needed to reduce uncertainties of how the soil $\mathrm{C}$ reservoir will respond to environmental change. Although several simulations rely on the amount of clay to reproduce changes in the balance of SOC, recent efforts have suggested that other soil physicochemical properties may serve as better predictors. Here we tested whether the effective cation exchange capacity (CEC eff.), may be a more suitable predictor of the content and potential preservation of SOC as compared to the mere quantification of clay-size particles. We further assessed how various climatic, vegetation and edaphic variables explain the variance of SOC content across different soil depths and soil $\mathrm{pH}$ classes. A set of more than 1000 forest 
Biogeosciences Discuss., https://doi.org/10.5194/bg-2019-33

Manuscript under review for journal Biogeosciences

Discussion started: 18 February 2019

(c) Author(s) 2019. CC BY 4.0 License.

sites across Switzerland, spanning a unique gradient of mean annual precipitation (636-2484 mm), altitude (277-2207 $\mathrm{m}$ a.s.1), $\mathrm{pH}(2.8-8.1)$ and representing different geologies and soil orders was used as a case study for this linear model analysis. Our results showed that CEC eff. has the largest explanatory potential of SOC content (35\% of response variance in the complete mineral soil profile) as compared to the amount of clay (which only explained $7 \%$ of the response variance in the complete mineral soil profile) and other environmental variables. CEC eff. is strongly linked to SOC especially in the top mineral soil $(0-30 \mathrm{~cm}$ depth) with the larger presence of organic matter. At deeper soil depths most of the variance in SOC is instead explained by climate, which in Switzerland is related to a greater weathering activity and translocation of organic $\mathrm{C}$ through leaching with increasing mean annual precipitation. We further observed soil $\mathrm{pH}$ to have a complex influence on SOC content, with CEC eff. being a dominant variable controlling SOC content at $\mathrm{pH}>4.5$ in the upper mineral soil and $\mathrm{pH}>6$ in the subsoil. Since CEC eff. is an edaphic property which is intimately associated to both the conditions that shaped the soil and the current edaphic physicochemical conditions, these findings indicate that considering CEC eff. as an integrative proxy for the potential preservation of SOC and its alteration could improve future predictions of how the soil $\mathrm{C}$ reservoir will feed back to environmental change.

\section{Introduction}

Large uncertainties in our understanding and predictions of how the terrestrial carbon (C) cycle interacts with alterations in the environment exist about the effects on the content of soil organic C (SOC) and its stabilization or destabilization (Jobbágy and Jackson, 2000; Friedlingstein et al., 2014; Jackson et al., 2017; Todd-Brown et al., 2013). To assess the impacts not only of the occurring but also of the forecasted global changes, it is desirable to identify environmental predictors of SOC dynamics (Bailey et al., 2018; Rasmussen et al., 2018; Harden et al., 2018), that match the recent shifts in paradigm of SOC (de)stabilization (Lehmann and Kleber, 2015; 
Biogeosciences Discuss., https://doi.org/10.5194/bg-2019-33

Manuscript under review for journal Biogeosciences

Discussion started: 18 February 2019

(c) Author(s) 2019. CC BY 4.0 License.

Schmidt et al., 2011). Measuring and predicting the content and potential preservation of SOC is elaborate due to the large spatial and temporal scales that are needed to detect changes (Harden et al., 2018; van der Voort et al., 2016). However, the exchange of knowledge between empirical research and simulation models offers great promise to facilitate innovations in $\mathrm{C}$ management and programs to reach climate-change mitigation goals, e.g. the ' 4 per mille Soils for Food Security and Climate' international research program (Minasny et al., 2017).

Advances in soil science have demonstrated that the content and preservation of SOC is not controlled by the chemical composition of organic matter alone but is rather predominantly driven by environmental and biological variables (Schmidt et al., 2011; Marschner et al., 2008; Kleber and Johnson, 2010). In this context, the effects of climatic, biotic, and geogenic controls of SOC dynamics have been extensively studied for different spatial and temporal scales (Davidson and Janssens, 2006; Hicks Pries et al., 2017; Jobbágy and Jackson, 2000; Falloon et al., 2011; Liang et al., 2017; Doetterl et al., 2015). Climatic variables generally appear to exert a major control of SOC dynamics and consequently a significant feedback of the terrestrial-C cycle to climate change is expected (Carvalhais et al., 2014; Chen et al., 2013). Biotic activity (plant and microbial) and soil physicochemical variables are additionally contributing to explain the large uncertainties covering the fate of SOC (Doetterl et al., 2015; Schmidt et al., 2011; Rasmussen et al., 2018; Torn et al., 1997).

Despite this improved understanding, model frameworks aimed at assessing how SOC responds to environmental change still necessitate the use of proxy variables that represent soil characteristics that cannot be measured (correlative proxies), or that aggregate information about multiple soil characteristics (integrative proxies) (Bailey et al., 2018). To improve projections of the largest actively cycling terrestrial $\mathrm{C}$ reservoir to environmental change, recent efforts have hence been focusing on identifying new sets of variables that can be used to determine the content of SOC. For instance, although several biogeochemical models rely on the amount of clay to simulate mineral protection of SOC (Coleman and Jenkinson, 1996; 
Biogeosciences Discuss., https://doi.org/10.5194/bg-2019-33

Manuscript under review for journal Biogeosciences

Discussion started: 18 February 2019

(c) Author(s) 2019. CC BY 4.0 License.

Wieder et al., 2015), Rasmussen et al. (2018) recently suggested that other soil physicochemical properties, such as exchangeable $\mathrm{Ca}$ or $\mathrm{Fe}$, and $\mathrm{Al}$ oxyhydroxides, can be used as better predictors depending on the local soil $\mathrm{pH}$. Soil $\mathrm{pH}$ reflects the chemical state of soil systems, e.g. protonation, controlled by geological and mineralogical properties, and dictates some of the main driving processes of SOC (de)stabilization (Deng and Dixon, 2002; Oades, 1988). Such processes include organo-mineral complexation, solubility and organism activity, which vary with depth across soil profiles (as reviewed by Sollins et al., 1996; Six et al., 2004; Trumbore, 2009).

The amount of clay, that is the soil mineral fraction $<2 \mu \mathrm{m}$ in size, influences the content of SOC by promoting the adsorption of organic molecules to its surfaces primarily by the interaction with pedogenic oxides and the aggregation within clay structures (Lützow et al., 2006; Oades, 1988; Eusterhues et al., 2003). Through its control on soil hydrology, oxygen availability as well as soil microbial community, the amount of clay can further indirectly alter SOC preservation (Andrews et al., 2011; Fierer and Schimel, 2002). Due to these properties, the amount of clay is often used as a proxy for sorption on mineral surfaces and aggregation of SOC, especially by more generalized larger scale models (Bailey et al., 2018). Several recent studies, however, did not find the amount of clay to be a predominant physicochemical predictor of SOC content and preservation (e.g. Schrumpf et al., 2013; Rasmussen et al., 2018; Doetterl et al., 2015). A reason for this is likely that the amount of clay merely represents a size class of soil particles rather an equivalent indication of available surface area or aggregate formation. It follows that other soil properties that represent an indication of available soil surfaces may be more appropriate to estimate SOC than clay.

An example of a soil property representing an indication of available soil surfaces is the effective cation exchange capacity (CEC eff.). CEC eff. is an edaphic property reflecting geology, mineralogical composition, organic matter and the $\mathrm{pH}$ that shapes the soil and its current physicochemical conditions. The CEC eff. of a soil represents the total amount of 
Biogeosciences Discuss., https://doi.org/10.5194/bg-2019-33

Manuscript under review for journal Biogeosciences

Discussion started: 18 February 2019

(c) Author(s) 2019. CC BY 4.0 License.

exchangeable cations such as $\mathrm{Na}^{+}, \mathrm{K}^{+}, \mathrm{Mg}^{2+}, \mathrm{Ca}^{2+}, \mathrm{Mn}^{2+}, \mathrm{Al}^{3+}, \mathrm{Fe}^{2+}, \mathrm{H}^{+}$that can be retained through electrostatic adsorption on soil particle surfaces. Soil particles exhibit negative and positive charges that can adsorb oppositely charged ions from the soil solution. In most soils, CEC eff. increases with soil $\mathrm{pH}$. At low $\mathrm{pH}$, it is mainly the permanent charges of the 2:1 type clays that adsorb exchangeable cations, while at higher $\mathrm{pH}$ values the negative charges on some 1:1-type clays, allophane, Fe- and Al- oxides, and soil organic matter increase, thereby increasing CEC eff. (Weil and Brady, 2016). There are several reasons why CEC eff. may be a better integrative proxy for the content and potential preservation of SOC than others. Quantifying the amount of clay is time-consuming. Determining clay mineralogy is expensive and requires specialized equipment, and quantification can be challenging. The key variables for soil organic matter protection are short range order minerals, $\mathrm{Al}$ - and $\mathrm{Fe}$ - oxyhydroxides, and Al-, Fe- organo-metal complexes (Rasmussen et al., 2018), which cannot be thoroughly identified and quantified for large sample sets with analytical techniques available today. Soil surface area that has been calculated by using gas adsorption as a proxy for the protective potential of soil and sediment, cannot be measured routinely on large sample sets. On the other hand, CEC eff. is measured routinely to assess soil fertility for agricultural and forest use.

Here we ask the question whether CEC eff. can serve as a new integrative proxy of SOC content and its potential preservation, integrating effects of soil surfaces of different clay types, short-range order mineral phases and organic matter at the actual soil $\mathrm{pH}$. Moreover, we are interested in understanding how the variance of SOC content is explained by various environmental variables across different soil depths and soil $\mathrm{pH}$ classes. We test this by using a set of more than 1000 forest soil profiles across Switzerland spanning a strong gradient of climate, altitude, geology, soil pH and soil orders (Gosheva et al., 2017).

\section{Materials and Methods}

\subsection{Study area and dataset}


Biogeosciences Discuss., https://doi.org/10.5194/bg-2019-33

Manuscript under review for journal Biogeosciences

Discussion started: 18 February 2019

(c) Author(s) 2019. CC BY 4.0 License.

The study area covers the complete country of Switzerland $\left(\sim 45-47^{\circ} \mathrm{N}, 6-10^{\circ} \mathrm{E}\right)$, situated in the centre of Europe. Switzerland offers a wide and intricate range of geology and topography which vary abruptly often within short distances, leading to very diverse soil orders (Walthert et al., 2013; Gosheva et al., 2017). About $30 \%$ of the country $\left(\sim 12.000 \mathrm{~km}^{2}\right)$ is covered by forest, and half of this area is located above $1000 \mathrm{~m}$ a.s.l. Forest management is mainly practiced at low elevations, where no large-scale clear-cutting is applied and natural regeneration is often fostered by silvicultural management (Brassel and Brändli, 1999). Forest soil fertilization and liming was always forbidden in Switzerland.

The dataset analyzed in this study originates from a database of the Swiss Federal Institute for Forest, Snow and Landscape Research (WSL) containing data on 1204 forest sites across Switzerland (for more details see Walthert et al., 2013; and Walthert and Meier, 2017). More than $80 \%$ of these sites have been covered for at least 150 years with forests (Gosheva et al., 2017).

The variables which we evaluated included SOC content $\left(\mathrm{g} \mathrm{kg}^{-1}\right)$ and other soil physicochemical properties ( $\mathrm{pH}$ in $\mathrm{CaCl}_{2}, \mathrm{CEC}$ eff. (mmolc $\mathrm{kg}^{-1}$ ) and soil texture) as well as climatic, topographic and vegetation data. In this study we report weighted means of SOC content over fixed depths rather than SOC stocks. This is because SOC content represents a direct measure of SOC after a single correction for the amount of fine earth in pedogenic horizons, while SOC stock estimates required multiple imponderable corrections (Gosheva et al., 2017).

\subsection{Soil chemical and physical properties}

In each forest site a soil profile was sampled by pedogenetic horizons down to a profile depth of $120 \mathrm{~cm}$ if possible, otherwise down to parent rock, with six samples per pit on average. Soil samples were dried at $40-60^{\circ} \mathrm{C}$ and sieved at $2 \mathrm{~mm}$ for chemical analyses. SOC content was measured in milled subsamples by dry combustion using a C/N analyser (NC 2500, Carlo Erba 
Biogeosciences Discuss., https://doi.org/10.5194/bg-2019-33

Manuscript under review for journal Biogeosciences

Discussion started: 18 February 2019

(c) Author(s) 2019. CC BY 4.0 License.

Instruments, Italy). Inorganic $\mathrm{C}$ was removed in samples with a $\mathrm{pH}$ above 6.0 by fumigating with $\mathrm{HCl}$ vapour prior to analysis (Walthert et al., 2010). Soil pH was measured potentiometrically in $0.01 \mathrm{M} \mathrm{CaCl}_{2}$ with a soil - extract ratio of $1: 2$ after 30 min of equilibration. Exchangeable cations were extracted in an unbuffered solution of $1 \mathrm{M} \mathrm{NH}_{4} \mathrm{Cl}$ for $1 \mathrm{~h}$ on an endover-end shaker using a soil - extract ratio of 1:10. The elemental concentrations were subsequently measured with an ICP-AES (Optima 3000, Perkin-Elmer). For soil samples with a $\mathrm{pH}\left(\mathrm{CaCl}_{2}\right)<6.5$ concentrations of exchangeable protons were calculated as the difference between the total and the Al-induced exchangeable acidity with the $\mathrm{KCl}$ method (Thomas, 1982). For soil samples with a higher $\mathrm{pH}$, concentrations of exchangeable protons were assumed to be negligible. The effective cation exchange capacity (CEC eff.) was finally calculated by summing the charge equivalents of exchangeable $\mathrm{Na}, \mathrm{K}, \mathrm{Mg}, \mathrm{Ca}, \mathrm{Mn}, \mathrm{Al}, \mathrm{Fe}$ and H. Grain size distribution was measured with the sedimentation method according to Gee and Bauder (1986) for 750 soil profiles. For the remaining soil profiles, we used the field estimates based on ten texture classes from Walthert et al. (2004). We focused on the following soil-depth intervals: $0-30 \mathrm{~cm}$ of the mineral soil profile (topsoil), $30-120 \mathrm{~cm}$ of the mineral soil profile (subsoil) and for a comprehensive interpretation of the data we also considered the complete mineral soil profile at $0-120 \mathrm{~cm}$. We calculated the mean average content of all the above mentioned soil properties for $0-30 \mathrm{~cm}, 30-120 \mathrm{~cm}$ and $0-120 \mathrm{~cm}$ by weighting the averages of the content with the amount of fine earth determined in the pedogenetic horizons of those fixed depth increments, as described in Walthert et al. (2013). Soil type was classified according to the World Reference Base from 2007 (IWG, 2007).

\subsection{Climatic, topographic and vegetation data}

The soil data of each forest site was paired with climatic and vegetation data. Climatic data was based on the Swiss metereological network (MeteoSwiss), combined with suitable interpolation algorithms (Walthert et al., 2013). Specifically, mean annual precipitation (MAP) and mean 
Biogeosciences Discuss., https://doi.org/10.5194/bg-2019-33

Manuscript under review for journal Biogeosciences

Discussion started: 18 February 2019

(c) Author(s) 2019. CC BY 4.0 License.

annual temperature (MAT) were provided by Meteotest (https://meteotest.ch/en/) for the period 1981-2010 (for details see Remund et al., 2014). The altitude of the forest sites was extracted from a $25 \mathrm{~m}$ digital elevation model (DEM) of the Federal Geo-Information centre swisstopo. For each forest site, the local Leaf Area Index (LAI) a common measure of canopy foliage acting as a control over primary production (Asner et al., 2003), was further estimated according to Schleppi et al. (2011) based on data from a vegetation survey using the Braun-Blanquet cover abundance scale (Braun-Blanquet, 1964; Mueller-Dombois and Ellenberg, 1974).

\subsection{Statistical analysis}

To identify which environmental variable of interest had the greatest prediction power on SOC content in the complete mineral soil profiles $(0-120 \mathrm{~cm})$, topsoils $(0-30 \mathrm{~cm})$ and subsoils $(30-$ $120 \mathrm{~cm}$ ), we applied linear model analysis. CEC eff., percentage of clay, LAI, MAT and, MAP were treated as explanatory variables while SOC content was treated as main response variable. To meet the normality assumptions of the applied statistical tests and standardize the variation among variables, we transformed the continuous variables to normal distributions applying logtransformations when required, and subsequently standardized them to a mean of 0 and standard deviation of 1 . The linear models were checked for multicollinearity using the variance inflation factor (VIF). The value of VIF $>4$ was set as a threshold for evidence of multicollinearity. We checked the model assumptions using the diagnostic plot functions in R (Crawley, 2012), and the normality of the residuals was tested using histograms. The explanatory power of the variables included in the linear models was computed as the standardized regression coefficient. The more positive or negative the coefficient is, the higher is its relative power in predicting the response variable SOC. We then partitioned the contribution of each of the explanatory variables to the explained variance in SOC employing hierarchical variance partitioning. For this, we used the 'Img' metric in the R package 'relaimpo' (Groemping and Matthias, 2006), which decomposes $\mathrm{R}$ squares into non-negative contributions that automatically sum to the total 
Biogeosciences Discuss., https://doi.org/10.5194/bg-2019-33

Manuscript under review for journal Biogeosciences

Discussion started: 18 February 2019

(c) Author(s) 2019. CC BY 4.0 License.

$\mathrm{R}$ squared of the linear model and takes care of the dependence on orderings by averaging over orderings (Grömping, 2006). The contribution of the environmental variables in explaining the variance of SOC was additionally normalized to sum to $100 \%$, i.e. in place of the total R squared (Groemping and Matthias, 2006). We further performed a linear model analysis of the relative importance of climatic, vegetation and edaphic variables to predict SOC across $\mathrm{pH}$ classes at 0-120 cm, 0-30 and 30-120 cm soil depth. Specifically, soil-pH data was grouped into nine consecutive $\mathrm{pH}$ ranges: $(\mathrm{pH}:<4,4-4.5,4.5-5,5-5.5,5.5-6,6-6.5,6.5-7,7-7.5,>7.5$ see Table 1 for the complete $\mathrm{pH}$ ranges at the three different depths). The relation between SOC content and all explanatory variables, parsed among different soil depths and $\mathrm{pH}$ classes, was also tested using Spearman's correlation coefficient. Significance was evaluated based on Bonferroni's corrected p-values to account for Type I errors. For each statistical test $\mathrm{P}<0.05$ was considered to be statistically significant. All analyses were performed with the R statistical software version 3.5.0 (R Core Team, 2018), and the packages 'vegan', 'MASS', 'dplyr', 'plyr', 'car', 'quantPsyc','caret','relaimpo', 'Psych'.

\section{Results}

\subsection{Environmental characteristics of the forest sites}

The Swiss forest sites where the soils were sampled are distributed between 277 and $2207 \mathrm{~m}$ a.s.l. They are characterized by a mean annual precipitation (MAP) ranging between 636 and $2484 \mathrm{~mm}$, and mean annual temperatures (MAT) ranging between 0.1 and $12.0^{\circ} \mathrm{C}$. MAT and altitude are strongly negatively correlated $(\mathrm{r}=-0.97)$. The predominant soil types are classified as Cambisols $(n=365)$, Luvisols $(n=127)$ and Gleysols $(n=89)$. About half of the sites are covered by broadleaf tree species while the rest are coniferous forests (Gosheva et al., 2017), with LAI values varying between 2 to 7.2 . $\mathrm{pH}$ values range from 2.8 to 8.1 and the percentage of clay varies between 0.8 and $75.6 \%$ (for details about specific ranges in topsoils and in the subsoils see Table 1). The parent material of the north of Switzerland is dominated by a 
Biogeosciences Discuss., https://doi.org/10.5194/bg-2019-33

Manuscript under review for journal Biogeosciences

Discussion started: 18 February 2019

(c) Author(s) 2019. CC BY 4.0 License.

calcareous bedrock and sediments, from which alkaline soils have developed. The most acidic soils are instead found in the Southern Alps and parts of the Swiss plateau, in the center of Switzerland (Figure S2). The content of SOC varies between 6 and $376.8 \mathrm{~g} \mathrm{~kg}^{-1}$ in topsoils (upper 0-30 $\mathrm{cm}$ of the mineral soil) and between 0 (lower than detection limit) and $229 \mathrm{~g} \mathrm{~kg}^{-1}$ in subsoils (30-120 cm depth). CEC eff. ranges between 20.4 and $1046.4 \mathrm{mmolc} \mathrm{kg}^{-1}$ in topsoils and between 6.2 and 727.9 mmolc $\mathrm{kg}^{-1}$ in subsoils.

\subsection{Predictors of soil organic carbon (complete pH range)}

All of the explanatory variables except MAT in the topsoil have a significant effect on SOC content when considering the complete $\mathrm{pH}$ range (Table 2). The standardized regression coefficients indicate that throughout Switzerland the SOC content increases with increasing CEC eff. and MAP, while decreases with greater MAT, LAI and percentage of clay. The signs of these relations are overall coherent with the sign of significant Pearson's correlations coefficients, with the exception of the correlation between SOC and CEC eff. in the $\mathrm{pH}$ range 4.5-5 in the subsoil (Fig. 1). The assessment of the relative contribution of the explanatory variables to the explained variance in SOC shows that within the complete mineral soil profile CEC eff. explains most of the response variance in SOC content (35\%), followed by MAP (26 $\%$ ), and smaller significant contributions of explained variance by LAI and MAT (Table 2). Within the topsoil CEC eff. also has the overall strongest influence on SOC accounting for 60 $\%$ of its variance (Table 2). In subsoils, climatic variables (MAP and MAT) are instead the predominant variables controlling the variance in SOC content (31 and $28 \%$ respectively) (Table 2).

\subsection{Soil organic carbon across pH classes}

SOC content is greater in more alkaline soils with $\mathrm{pH}>5.5$ (Fig. S1). The relative contribution of the explanatory variables to the explained variance in SOC is dependent upon $\mathrm{pH}$ (Fig. 1, 
Biogeosciences Discuss., https://doi.org/10.5194/bg-2019-33

Manuscript under review for journal Biogeosciences

Discussion started: 18 February 2019

(c) Author(s) 2019. CC BY 4.0 License.

Fig. 2). For lower $\mathrm{pH}$ classes, MAP explains the largest portion of the response variance of SOC content, while CEC eff. explains the greatest portion of variance in more alkaline soils Fig. 3 presents the normalized contribution of MAP, MAT, LAI, percent clay and CEC eff. in explaining the variance of SOC content. The total amount of variance explained (R squared) by each independent linear model across pH classes ranges between $0.76(0-30 \mathrm{~cm}$ depth, $\mathrm{pH}$ 66.5) and 0.11 (30-120 cm depth, $\mathrm{pH} 5.5-6)$ (Fig. 4). On average, each pH class contains $125 \pm 94$ (mean \pm SD) forest sites that we could analyze with independent linear models (Fig. 4). The total amount of variance explained by the linear model runs is independent from the number of forest sites included in the models.

\section{Discussion}

\subsection{Can the effective cation exchange capacity be used as a proxy for soil organic carbon content?}

Our linear model analysis indicates that throughout 1204 Swiss forest sites, encompassing a pronounced gradient of climate, geology, soil $\mathrm{pH}$ and soil orders, CEC eff. has the largest explanatory potential of SOC content $(35 \%$ of response variance in the complete mineral soil profile) as compared to other environmental variables (Table 2). Since CEC eff. is an edaphic property which is intimately associated to both the conditions that shaped the soil and the current physicochemical conditions in the soil, the significant link between CEC eff. and SOC hints towards a potential of this edaphic property to be used as an integrative proxy of the present and future content of SOC. In our evaluation we included a range of climatic, vegetation and edaphic properties, as these variables are commonly regarded as primary controls of SOC (Torn et al., 2009). However, we cannot rule out that our analysis could be biased by the lack of available information on the activity by soil organisms (microbial communities and soil macro- and meso- fauna) (Jackson et al., 2017). The weak relationship between the vegetation 
Biogeosciences Discuss., https://doi.org/10.5194/bg-2019-33

Manuscript under review for journal Biogeosciences

Discussion started: 18 February 2019

(c) Author(s) 2019. CC BY 4.0 License.

property we adopted as an indication of plant primary production (the LAI) and SOC content strongly suggests that the quantity of litter inputs is less important for SOC than physicochemical properties. This is in agreement with mechanistic studies employing isotopic tracers, as well as spectroscopic and molecular techniques (Hagedorn et al., 2003; Marschner et al., 2008; Schmidt et al., 2011). The weak relationship may however also result from the lack of information on the growth of belowground plant biomass as well as on differing decomposition rates of above and belowground plant debris before incorporation into the soil (Hobbie et al., 2010). Nevertheless, the results of our analysis clearly demonstrate that CEC eff. explains a larger portion of the variance in SOC content than the percentage of clay - on which many biogeochemical models rely as a proxy of SOC. Such pattern might be partly related to the contribution of variably charged functional groups of organic matter to CEC eff. but it also corroborates the emerging conceptual understanding that other soil physicochemical properties predict the content and potential persistence of SOC better than the amount of clay (e.g. Rasmussen et al., 2018).

\subsection{How is the variance of soil organic carbon content explained by environmental variables at different soil depths?}

In agreement with vast ranging observations showing that SOC content decreases with soil depth (e.g. Jobbágy and Jackson, 2000; Rumpel and Kögel-Knabner, 2011), we observed a higher SOC content in the upper $30 \mathrm{~cm}$ of the mineral soil as compared to that found at lower depths (Table 2). This pattern is commonly related to a decline in the inputs of plant-derived organic matter with depth because litterfall from leaves, needles and twigs occurs on the soil surface, and this material is only partially translocated to the subsoil in dissolved form or via bioturbation. Moreover, plant root densities are commonly smaller in subsoils than in topsoils (Jackson et al., 1997). Microbial communities involved in the breakdown of organic matter also vary across depth profiles (e. g. Lindahl et al., 2007). Our linear model analysis demonstrates 
Biogeosciences Discuss., https://doi.org/10.5194/bg-2019-33

Manuscript under review for journal Biogeosciences

Discussion started: 18 February 2019

(c) Author(s) 2019. CC BY 4.0 License.

that CEC eff. is the strongest predictor of SOC in topsoils (explaining $60 \%$ of the total variance in SOC content) while climatic variables (MAT and MAP) are stronger predictors of SOC in subsoils (Table 2). The primary influence of CEC eff. on SOC content in topsoils as compared to deeper soil depths can be attributed to the overall larger presence of organic matter that contributes markedly to a higher number of available negative charges in soils to which cations can bind. The dominant control of climate on the content of SOC in subsoils is instead connected to a significant transport of fresh $\mathrm{C}$ to deeper soil depths through leaching of dissolved organic matter (Kaiser and Guggenberger, 2000), which increases with increasing precipitation and a greater accumulation of organic horizons, especially under cool and humid climatic conditions (Gosheva et al., 2017). Analyses of the content of SOC in the soil solution and in the organic debris residing inside and outside aggregates and bound to minerals would be necessary to test these mechanisms across complete soil profiles in Swiss forest sites.

\subsection{How does soil pH influence the variance of soil organic carbon content explained by different environmental variables?}

Overall, we observed a significant and complex influence of soil $\mathrm{pH}$ on the content of SOC confirming results from previous studies (Rasmussen et al., 2018; Newcomb et al., 2017). Our study provided a unique soil $\mathrm{pH}$ gradient (spanning from 2.8 to 8.1 , Fig. S2) which largely resulted from the complex topography and orogeny of the territory of Switzerland encompassing various types of parent material, made up of sedimentary, crystalline or metamorphic rocks with highly variable mineralogical compositions (Gosheva et al., 2017). We found that SOC content is higher in more alkaline soils with $\mathrm{pH}>5.5$ (Fig. S1). However, it has to be noted that SOC stocks in Swiss forests are generally not higher in calcareous than acidic soils (Gosheva et al., 2017), indicating that acidic soils e.g. in the South of Switzerland (Fig. S2), have a lower SOC content but are generally deeper. Moreover, our analysis revealed that the relative control of climatic, vegetation and edaphic variables on SOC evolves as a function 
Biogeosciences Discuss., https://doi.org/10.5194/bg-2019-33

Manuscript under review for journal Biogeosciences

Discussion started: 18 February 2019

(c) Author(s) 2019. CC BY 4.0 License.

of soil $\mathrm{pH}$. MAP explained most of the variance in SOC content at low $\mathrm{pH}(\mathrm{pH}<5.5)$, while CEC eff. was the dominant variable at higher $\mathrm{pH}$ values $(\mathrm{pH}>4.5$ in topsoils and $\mathrm{pH}>6$ in subsoils) (Fig. 2).

The strong influence of MAP on SOC that we observed at low $\mathrm{pH}$ is likely primarily related to the reaction of organic ligands with aluminium cations $\left(\mathrm{Al}^{3+}\right)$ that often occurs in many soils of regions with a high MAP and thus high water availabilities (Chadwick and Chorover, 2001; Torn et al., 1997; Blaser et al., 1997; Blaser and Sposito, 1987; Eckmeier et al., 2010). Firstly, in acid soils the presence of $\mathrm{Al}^{3+}$ cations is commonly associated to the production of organo-metal complexes during the process of weathering. Secondly, a strong chelation of $\mathrm{Al}^{3+}$ by organic acids in Swiss forest soils characterized by a high MAP and acid soils, is pointed out by the high levels of exchangeable aluminium $\left(\mathrm{Al}^{3+}\right)$ found at low $\mathrm{pH}$ classes (Fig. S1), and by the observation of the highest MAP regimes in regions with the most acidic soils (Fig. S2, S3). These patterns corroborate previous results showing that the relatively humid climate of the Southern Alps promotes both the formation of pedogenic oxides and the leaching of dissolved organic $\mathrm{C}$ from the organic layer to the mineral soil, where organic matter i.e. tannins and other polyphenols forms organo-metal complexes (Eckmeier et al., 2010). The peak in the explanatory power of MAP on the content of SOC at $\mathrm{pH} 4.5-5$ (Fig. 3) is probably related to the greater occurrence of Luvisols and Podzols in this $\mathrm{pH}$ range (Fig. S4). These soil orders are characterized by translocation of clay and organic matter.

The dominant contribution of CEC eff. in explaining the variance of SOC in higher $\mathrm{pH}$ classes can be explained by the established knowledge that the amount of available negative charges to which cations can be bound on organic matter - together as on allophane and some 1:1-type clays - increase with rising $\mathrm{pH}$ (Weil and Brady, 2016). In particular, the deprotonation of carboxyl and hydroxyl groups present in organic matter has often been observed to contribute markedly to the greater number of available negative charges in soils, and more so at higher $\mathrm{pH}$ values (Krishnaswamy and Richter, 2002; Tate and Theng, 1980; Sullivan et al., 2006). 
Biogeosciences Discuss., https://doi.org/10.5194/bg-2019-33

Manuscript under review for journal Biogeosciences

Discussion started: 18 February 2019

(c) Author(s) 2019. CC BY 4.0 License.

Furthermore at $\mathrm{pH}$ levels higher than 6 the charges of 2:1-type clays have been observed to increase due to a deprotonation of exposed hydroxyl functional groups (Tournassat et al., 2016).

\section{Conclusions}

In conclusion, our study of Swiss forest soils provides a first indication that CEC eff. could be used as an integrative proxy of SOC content and its potential preservation. Determining whether CEC eff. is an effective proxy for the content of SOC also in non-forested ecosystems and in other geographical locations would be a further step forward to test its broad applicability in Earth System models. This information could be compiled starting from available soil profile samples, soil surveys and monitoring programs at the country, continental or climatic zone level (e.g. http://icp-forests.net/, http://ncsslabdatamart.sc.egov.usda.gov/). Some global gridded data about CEC. eff has also already been derived (Hengl et al., 2017) by the international soil reference and information center ISRIC. We observed that CEC eff and SOC are closely linked especially in the top mineral soil $(0-30 \mathrm{~cm}$ depth) as compared to deeper depths. This is due to the overall larger presence of organic matter contributing to a higher number of available negative charges in topsoils. In subsoils most of the variance in SOC is instead explained by climate, which in our study is potentially related to increasing weathering and transport of fresh C to greater soil depths through leaching of dissolved organic matter with increasing MAP. Soil $\mathrm{pH}$ strongly affects the explanatory power of CEC eff. on the content of SOC in Swiss forest soils, with CEC eff. being the dominant variable at $\mathrm{pH}>4.5$ in topsoils and $\mathrm{pH}>6$ in subsoils. Since $73 \%$ of the land surface is covered by soils with $\mathrm{pH}>5.5$ (area calculated according to the global pH dataset IGBP-DIS (1998)) the consideration of CEC eff. as an integrative proxy for the potential alterations of SOC content could strengthen our ability to predict future changes in the belowground $\mathrm{C}$ reservoir. 
Biogeosciences Discuss., https://doi.org/10.5194/bg-2019-33

Manuscript under review for journal Biogeosciences

Discussion started: 18 February 2019

(c) Author(s) 2019. CC BY 4.0 License.

\section{Author contributions}

MWIS, SZ, FH conceived the idea of this analysis, SZ and LW provided and quality checked the data, EFS developed the ideas for this manuscript and considering the preliminary analyses by VW defined the final statistical approach. EFS prepared and wrote the manuscript with contributions from all co-authors.

\section{Acknowledgements}

Evaluations were partly based on data from the Swiss Long-term Forest Ecosystem Research programme LWF (www.lwf.ch), which is part of the UNECE Co-operative Programme on Assessment and Monitoring of Air Pollution Effects on Forests ICP Forests (www.icpforests.net). We are in particular grateful to Peter Jakob for his contribution to the soil database, and the technical staff of the WSL research unit Forest Soils and Biogeochemistry for collecting and analyzing the soil samples. This study was financed by the Swiss National Science Foundation SNSF project 'Deep C' (number 172744) and the University Research Priority Program for Global Change and Biodiversity of the University of Zurich. Data supporting this paper is provided in a separate data Table.

\section{Competing interests}

The authors declare no competing interests.

\section{References}

Andrews, D. M., Lin, H., Zhu, Q., Jin, L., and Brantley, S. L.: Hot Spots and Hot Moments of Dissolved Organic Carbon Export and Soil Organic Carbon Storage in the Shale Hills Catchment, Vadose Zone Journal, 10, 943-954, 10.2136/vzj2010.0149, 2011. 
Biogeosciences Discuss., https://doi.org/10.5194/bg-2019-33

Manuscript under review for journal Biogeosciences

Discussion started: 18 February 2019

(c) Author(s) 2019. CC BY 4.0 License.

Asner, G. P., Scurlock, J. M., and A. Hicke, J.: Global synthesis of leaf area index observations: implications for ecological and remote sensing studies, Global Ecology and Biogeography, 12, 191-205, 2003.

Bailey, V. L., Bond-Lamberty, B., DeAngelis, K., Grandy, A. S., Hawkes, C. V., Heckman, K., Lajtha, K., Phillips, R. P., Sulman, B. N., Todd-Brown, K. E. O., and Wallenstein, M. D.: Soil carbon cycling proxies: Understanding their critical role in predicting climate change feedbacks, Global Change Biology, 24, 895-905, doi:10.1111/gcb.13926, 2018.

Blaser, P., and Sposito, G.: Spectrofluorometric Investigation of Trace Metal Complexation by an Aqueous Chestnut Leaf Litter Extract1, Soil Science Society of America Journal, 51, 612-619, 10.2136/sssaj1987.03615995005100030011x, 1987.

Blaser, P., Kernebeek, P., Tebbens, L., Van Breemen, N., and Luster, J.: Cryptopodzolic Soils in Switzerland, European Journal of Soil Science, 48, 411-423, doi:10.1111/j.13652389.1997.tb00207.x, 1997.

Brassel, P., and Brändli, U.: Schweizerisches Landesforstinventar. Ergebnisse der Zweitaufnahme 1993-1995, Eidgenössische Forschungsanstalt für Wald und Schnee und Landschaft, Bundesamt für Umwelt und Wald und Landschaft, Bern: Haupt Verlag, 1999.

Braun-Blanquet, J.: Pflanzensoziologie: Grundzuge der Vegetationkunde, Springer, 1964.

Carvalhais, N., Forkel, M., Khomik, M., Bellarby, J., Jung, M., Migliavacca, M., u, M., Saatchi, S., Santoro, M., Thurner, M., Weber, U., Ahrens, B., Beer, C., Cescatti, A., Randerson, J. T., and Reichstein, M.: Global covariation of carbon turnover times with climate in terrestrial ecosystems, Nature, 514, 213-217, 2014.

Chadwick, O. A., and Chorover, J.: The chemistry of pedogenic thresholds, Geoderma, 100, 321-353, https://doi.org/10.1016/S0016-7061(01)00027-1, 2001.

Chen, S., Huang, Y., Zou, J., and Shi, Y.: Mean residence time of global topsoil organic carbon depends on temperature, precipitation and soil nitrogen, Global and Planetary Change, 100, 99-108, https://doi.org/10.1016/j.gloplacha.2012.10.006, 2013. 
Biogeosciences Discuss., https://doi.org/10.5194/bg-2019-33

Manuscript under review for journal Biogeosciences

Discussion started: 18 February 2019

(c) Author(s) 2019. CC BY 4.0 License.

Coleman, K., and Jenkinson, D.: RothC-26.3-A Model for the turnover of carbon in soil, in: Evaluation of soil organic matter models, Springer, 237-246, 1996.

Crawley, M. J.: The R book, John Wiley \& Sons, 2012.

Davidson, E. A., and Janssens, I. A.: Temperature sensitivity of soil carbon decomposition and feedbacks to climate change, Nature, 440, 165, 10.1038/nature04514, 2006.

Deng, Y., and Dixon, J. B.: Soil organic matter and organic-mineral interactions, Soil mineralogy with environmental applications, 69-107, 2002.

Doetterl, S., Stevens, A., Six, J., Merckx, R., Van Oost, K., Casanova Pinto, M., CasanovaKatny, A., Muñoz, C., Boudin, M., Zagal Venegas, E., and Boeckx, P.: Soil carbon storage controlled by interactions between geochemistry and climate, Nature Geoscience, 8, 780, 2015.

Eckmeier, E., Egli, M., Schmidt, M. W. I., Schlumpf, N., Nötzli, M., Minikus-Stary, N., and Hagedorn, F.: Preservation of fire-derived carbon compounds and sorptive stabilisation promote the accumulation of organic matter in black soils of the Southern Alps, Geoderma, 159, 147-155, https://doi.org/10.1016/j.geoderma.2010.07.006, 2010.

Eusterhues, K., Rumpel, C., Kleber, M., and Kögel-Knabner, I.: Stabilisation of soil organic matter by interactions with minerals as revealed by mineral dissolution and oxidative degradation,

Organic

Geochemistry,

34

1591-1600, https://doi.org/10.1016/j.orggeochem.2003.08.007, 2003.

Falloon, P., Jones, C. D., Ades, M., and Paul, K.: Direct soil moisture controls of future global soil carbon changes: An important source of uncertainty, Global Biogeochemical Cycles, 25, doi:10.1029/2010GB003938, 2011.

Fierer, N., and Schimel, J. P.: Effects of drying-rewetting frequency on soil carbon and nitrogen transformations, Soil Biology and Biochemistry, 34, 777-787, https://doi.org/10.1016/S0038-0717(02)00007-X, 2002. 
Biogeosciences Discuss., https://doi.org/10.5194/bg-2019-33

Manuscript under review for journal Biogeosciences

Discussion started: 18 February 2019

(c) Author(s) 2019. CC BY 4.0 License.

Friedlingstein, P., Meinshausen, M., Arora, V. K., Jones, C. D., Anav, A., Liddicoat, S. K., and Knutti, R.: Uncertainties in CMIP5 climate projections due to carbon cycle feedbacks, Journal of Climate, 27, 511-526, 2014.

Gee, G. W., and Bauder, J. W.: Particle-size analysis 1, methodsofsoilan1, Soil Science Society of America, American Society of Agronomy, 1986.

Gosheva, S., Walthert, L., Niklaus, P. A., Zimmermann, S., Gimmi, U., and Hagedorn, F.: Reconstruction of Historic Forest Cover Changes Indicates Minor Effects on Carbon Stocks in Swiss Forest Soils, Ecosystems, 20, 1512-1528, 10.1007/s10021-017-0129-9, 2017.

Groemping, U., and Matthias, L.: Package "relaimpo": Relative importance of regressors in linear models, R package version, 1.1-1, 2006.

Grömping, U.: Relative importance for linear regression in R: the package relaimpo, Journal of statistical software, 17, 1-27, 2006.

Hagedorn, F., Spinnler, D., Bundt, M., Blaser, P., and Siegwolf, R.: The input and fate of new C in two forest soils under elevated CO2, Global Change Biology, 9, 862-872, 2003.

Harden, J. W., Hugelius, G., Ahlström, A., Blankinship, J. C., Bond-Lamberty, B., Lawrence, C. R., Loisel, J., Malhotra, A., Jackson, R. B., Ogle, S., Phillips, C., Ryals, R., Todd-Brown, K., Vargas, R., Vergara, S. E., Cotrufo, M. F., Keiluweit, M., Heckman, K. A., Crow, S. E., Silver, W. L., DeLonge, M., and Nave, L. E.: Networking our science to characterize the state, vulnerabilities, and management opportunities of soil organic matter, Global Change Biology, 24, e705-e718, doi:10.1111/gcb.13896, 2018.

Hengl, T., de Jesus, J. M., Heuvelink, G. B., Gonzalez, M. R., Kilibarda, M., Blagotić, A., Shangguan, W., Wright, M. N., Geng, X., and Bauer-Marschallinger, B.: SoilGrids250m: Global gridded soil information based on machine learning, PLoS one, 12, e0169748, 2017. Hicks Pries, C. E., Castanha, C., Porras, R. C., and Torn, M. S.: The whole-soil carbon flux in response to warming, Science, 355, 1420-1423, 10.1126/science.aal1319, 2017. 
Biogeosciences Discuss., https://doi.org/10.5194/bg-2019-33

Manuscript under review for journal Biogeosciences

Discussion started: 18 February 2019

(c) Author(s) 2019. CC BY 4.0 License.

Hobbie, S. E., Oleksyn, J., Eissenstat, D. M., and Reich, P. B.: Fine root decomposition rates do not mirror those of leaf litter among temperate tree species, Oecologia, 162, 505-513, 2010.

IGBP-DIS, S.: A program for creating global soil-property databases, IGBP Global Soils Data Task, France, 1998.

IWG, W.: World reference base for soil resources 2006, first update 2007, FAO: Rome. Available at: www. fao. org, 2007.

Jackson, R. B., Mooney, H., and Schulze, E.-D.: A global budget for fine root biomass, surface area, and nutrient contents, Proceedings of the National Academy of Sciences, 94, 7362$7366,1997$.

Jackson, R. B., Lajtha, K., Crow, S. E., Hugelius, G., Kramer, M. G., and Piñeiro, G.: The Ecology of Soil Carbon: Pools, Vulnerabilities, and Biotic and Abiotic Controls, Annual Review of Ecology, Evolution, and Systematics, 48, 419-445, 10.1146/annurev-ecolsys$112414-054234,2017$

Jobbágy, E. G., and Jackson, R. B.: The vertical distribution of soil organic carbon and its relation to climate and vegetation, Ecological Applications, 10, 423-436, 2000.

Kaiser, K., and Guggenberger, G.: The role of DOM sorption to mineral surfaces in the preservation of organic matter in soils, Organic Geochemistry, 31, 711-725, https://doi.org/10.1016/S0146-6380(00)00046-2, 2000.

Kleber, M., and Johnson, M. G.: Advances in understanding the molecular structure of soil organic matter: implications for interactions in the environment, in: Advances in agronomy, Elsevier, 77-142, 2010.

Krishnaswamy, J., and Richter, D. D.: Properties of Advanced Weathering-Stage Soils in Tropical Forests and Pastures, Soil Science Society of America Journal, 66, 244-253, 10.2136/sssaj2002.2440, 2002. 
Biogeosciences Discuss., https://doi.org/10.5194/bg-2019-33

Manuscript under review for journal Biogeosciences

Discussion started: 18 February 2019

(c) Author(s) 2019. CC BY 4.0 License.

Lehmann, J., and Kleber, M.: The contentious nature of soil organic matter, Nature, 528, 60, 10.1038/nature16069, 2015.

Liang, C., Schimel, J. P., and Jastrow, J. D.: The importance of anabolism in microbial control over soil carbon storage, Nature Microbiology, 2, 17105, 10.1038/nmicrobiol.2017.105, 2017.

Lindahl, B. D., Ihrmark, K., Boberg, J., Trumbore, S. E., Högberg, P., Stenlid, J., and Finlay, R. D.: Spatial separation of litter decomposition and mycorrhizal nitrogen uptake in a boreal forest, New Phytologist, 173, 611-620, 2007.

Lützow, M. v., Kögel-Knabner, I., Ekschmitt, K., Matzner, E., Guggenberger, G., Marschner, B., and Flessa, H.: Stabilization of organic matter in temperate soils: mechanisms and their relevance under different soil conditions - a review, European Journal of Soil Science, 57, 426-445, doi:10.1111/j.1365-2389.2006.00809.x, 2006.

Marschner, B., Brodowski, S., Dreves, A., Gleixner, G., Gude, A., Grootes, P. M., Hamer, U., Heim, A., Jandl, G., and Ji, R.: How relevant is recalcitrance for the stabilization of organic matter in soils?, Journal of plant nutrition and soil science, 171, 91-110, 2008.

Minasny, B., Malone, B. P., McBratney, A. B., Angers, D. A., Arrouays, D., Chambers, A., Chaplot, V., Chen, Z.-S., Cheng, K., Das, B. S., Field, D. J., Gimona, A., Hedley, C. B., Hong, S. Y., Mandal, B., Marchant, B. P., Martin, M., McConkey, B. G., Mulder, V. L., O'Rourke, S., Richer-de-Forges, A. C., Odeh, I., Padarian, J., Paustian, K., Pan, G., Poggio, L., Savin, I., Stolbovoy, V., Stockmann, U., Sulaeman, Y., Tsui, C.-C., Vågen, T.-G., van Wesemael, B., and Winowiecki, L.: Soil carbon 4 per mille, Geoderma, 292, 59-86, https://doi.org/10.1016/j.geoderma.2017.01.002, 2017.

Mueller-Dombois, D., and Ellenberg, H.: Aims and methods of vegetation ecology, New York, London, Sydney, Toronto, 1974. 
Biogeosciences Discuss., https://doi.org/10.5194/bg-2019-33

Manuscript under review for journal Biogeosciences

Discussion started: 18 February 2019

(c) Author(s) 2019. CC BY 4.0 License.

Newcomb, C. J., Qafoku, N. P., Grate, J. W., Bailey, V. L., and De Yoreo, J. J.: Developing a molecular picture of soil organic matter-mineral interactions by quantifying organomineral binding, Nature Communications, 8, 396, 10.1038/s41467-017-00407-9, 2017.

Oades, J. M.: The Retention of Organic Matter in Soils, Biogeochemistry, 5, 35-70, 1988.

R Core Team. 2018. R: A language and environment for statistical computing. R Foundation $\mathrm{f}$ or Statistical Computing, Vienna, Austria. URL https://www.R-project.org/.

Rasmussen, C., Heckman, K., Wieder, W. R., Keiluweit, M., Lawrence, C. R., Berhe, A. A., Blankinship, J. C., Crow, S. E., Druhan, J. L., Hicks Pries, C. E., Marin-Spiotta, E., Plante, A. F., Schädel, C., Schimel, J. P., Sierra, C. A., Thompson, A., and Wagai, R.: Beyond clay: towards an improved set of variables for predicting soil organic matter content, Biogeochemistry, 137, 297-306, 10.1007/s10533-018-0424-3, 2018.

Remund, J., Rihm, B., and Huguenin-Landl, B.: Klimadaten für die Waldmodellierung für das 20. und 21. Jahrhundert Schlussbericht. Forschungsprogramm „Wald und Klimawandel“‘ des Bundesamtes für Umwelt BAFU, Bern und der Eidg. Forschungsanstalt WSL, Birmensdorf., Meteotest, Bern, 2014.

Rumpel, C., and Kögel-Knabner, I.: Deep soil organic matter-a key but poorly understood component of terrestrial C cycle, Plant and soil, 338, 143-158, 2011.

Schleppi, P., Thimonier, A., and Walthert, L.: Estimating leaf area index of mature temperate forests using regressions on site and vegetation data, Forest Ecology and Management, 261, 601-610, https://doi.org/10.1016/j.foreco.2010.11.013, 2011.

Schmidt, M. W., Torn, M. S., Abiven, S., Dittmar, T., Guggenberger, G., Janssens, I. A., Kleber, M., Kögel-Knabner, I., Lehmann, J., and Manning, D. A.: Persistence of soil organic matter as an ecosystem property, Nature, 478, 49-56, 2011.

Schrumpf, M., Kaiser, K., Guggenberger, G., Persson, T., Kögel-Knabner, I., and Schulze, E. D.: Storage and stability of organic carbon in soils as related to depth, occlusion within 
Biogeosciences Discuss., https://doi.org/10.5194/bg-2019-33

Manuscript under review for journal Biogeosciences

Discussion started: 18 February 2019

(c) Author(s) 2019. CC BY 4.0 License.

aggregates, and attachment to minerals, Biogeosciences, 10, 1675-1691, 10.5194/bg-10$1675-2013,2013$.

Six, J., Bossuyt, H., Degryze, S., and Denef, K.: A history of research on the link between (micro) aggregates, soil biota, and soil organic matter dynamics, Soil and Tillage Research, 79, 7-31, 2004.

Sollins, P., Homann, P., and Caldwell, B. A.: Stabilization and destabilization of soil organic matter: mechanisms and controls, Geoderma, 74, 65-105, https://doi.org/10.1016/S00167061(96)00036-5, 1996.

Sullivan, T. J., Fernandez, I. J., Herlihy, A. T., Driscoll, C. T., McDonnell, T. C., Nowicki, N. A., Snyder, K. U., and Sutherland, J. W.: Acid-base characteristics of soils in the Adirondack Mountains, New York, Soil Science Society of America Journal, 70, 141-152, 2006.

Tate, K., and Theng, B.: Organic matter and its interactions with inorganic soil constituents, Soils with variable charge, 225-249, 1980.

Thomas, G. W.: Exchangeable cations, Methods of soil analysis. Part 2. Chemical and microbiological properties, 159-165, 1982.

Todd-Brown, K. E. O., Randerson, J. T., Post, W. M., Hoffman, F. M., Tarnocai, C., Schuur, E. A. G., and Allison, S. D.: Causes of variation in soil carbon simulations from CMIP5 Earth system models and comparison with observations, Biogeosciences, 10, 1717-1736, 10.5194/bg-10-1717-2013, 2013.

Torn, M., Swanston, C., Castanha, C., and Trumbore, S.: Storage and turnover of organic matter in soil, Biophysico-chemical processes involving natural nonliving organic matter in environmental systems. Wiley, Hoboken, 219-272, 2009.

Torn, M. S., Trumbore, S. E., Chadwick, O. A., Vitousek, P. M., and Hendricks, D. M.: Mineral control of soil organic carbon storage and turnover, Nature, 389, 170, 10.1038/38260, 1997. 
Biogeosciences Discuss., https://doi.org/10.5194/bg-2019-33

Manuscript under review for journal Biogeosciences

Discussion started: 18 February 2019

(c) Author(s) 2019. CC BY 4.0 License.

Tournassat, C., Davis, J. A., Chiaberge, C., Grangeon, S., and Bourg, I. C.: Modeling the AcidBase Properties of Montmorillonite Edge Surfaces, Environmental Science \& Technology, 50, 13436-13445, 10.1021/acs.est.6b04677, 2016.

Trumbore, S.: Radiocarbon and soil carbon dynamics, Annual Review of Earth and Planetary Sciences, 37, 47-66, 2009.

van der Voort, T. S., Hagedorn, F., McIntyre, C., Zell, C., Walthert, L., Schleppi, P., Feng, X., and Eglinton, T. I.: Variability in 14C contents of soil organic matter at the plot and regional scale across climatic and geologic gradients, Biogeosciences Discuss., 2016, 1-28, 10.5194/bg-2015-649, 2016.

Walthert, L., Zimmermann, S., Blaser, P., Luster, J., and Lüscher, P.: Waldböden der Schweiz, hep Verlag Bern, Switzerland, 2004.

Walthert, L., Graf, U., Kammer, A., Luster, J., Pezzotta, D., Zimmermann, S., and Hagedorn, F.: Determination of organic and inorganic carbon, $\delta 13 \mathrm{C}$, and nitrogen in soils containing carbonates after acid fumigation with $\mathrm{HCl}$, Journal of Plant Nutrition and Soil Science, 173, 207-216, doi:10.1002/jpln.200900158, 2010.

Walthert, L., Graf Pannatier, E., and Meier, E. S.: Shortage of nutrients and excess of toxic elements in soils limit the distribution of soil-sensitive tree species in temperate forests, Forest Ecology and Management, 94-107, https://doi.org/10.1016/j.foreco.2013.02.008, 2013.

Walthert, L., and Meier, E. S.: Tree species distribution in temperate forests is more influenced by soil than by climate, Ecology and Evolution, 7, 9473-9484, doi:10.1002/ece3.3436, 2017.

Weil, R., and Brady, N. C.: Nature and properties of soils, the: Pearson new international edition, Pearson Higher Ed, 2016. 
Biogeosciences Discuss., https://doi.org/10.5194/bg-2019-33

Manuscript under review for journal Biogeosciences

Discussion started: 18 February 2019

(c) Author(s) 2019. CC BY 4.0 License.

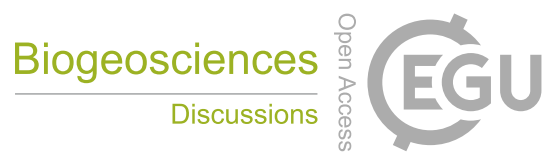

(c) (i)

612 Wieder, W. R., Grandy, A. S., Kallenbach, C. M., Taylor, P. G., and Bonan, G. B.: Representing

613 life in the Earth system with soil microbial functional traits in the MIMICS model, Geosci.

614 Model Dev., 8, 1789-1808, 10.5194/gmd-8-1789-2015, 2015. 
Biogeosciences Discuss., https://doi.org/10.5194/bg-2019-33

Manuscript under review for journal Biogeosciences

Discussion started: 18 February 2019

(c) Author(s) 2019. CC BY 4.0 License.

\section{Figures:}

Fig. 1: Pearson's correlations between the content of SOC and explanatory variables for (a) complete mineral soil profiles (0-120 cm depth), (b) topsoils (0-30 cm depth), (c) subsoils (30$120 \mathrm{~cm}$ depth). MAP, mean annual precipitation (mm), MAT, mean annual temperature $\left({ }^{\circ} \mathrm{C}\right)$, LAI, leaf area index, clay, percentage of clay (\%), CEC, effective cation exchange capacity $\left(\right.$ mmolc $\left.\mathrm{kg}^{-1}\right)$. Those correlations with $\mathrm{P}>0.05$ are considered not significant (NS) based on Bonferroni’s correction.

Fig. 2: Amount of explained variance by climatic, vegetation and edaphic variables in predicting the content of SOC $\left(\mathrm{g} \mathrm{kg}^{-1}\right)$ across $\mathrm{pH}$ classes for (a) complete mineral soil profiles (0-120 cm depth), (b) topsoils (0-30 cm depth), (c) subsoils (30-120 cm depth). Horizontal bars show the amount of variance explained by each variable ( $\mathrm{R}$ squared) in the linear models as calculated using the 'lmg' metric in the R package 'relaimpo'. Significant variables (pvalue $<0.05)$ are marked by an asterisk $\left(^{*}\right)$. MAP, mean annual precipitation $(\mathrm{mm})$, MAT, mean annual temperature $\left({ }^{\circ} \mathrm{C}\right)$, LAI, leaf area index, clay, percentage of clay $(\%)$, CEC, effective cation exchange capacity (mmolc $\mathrm{kg}^{-1}$ ). The total amount of variance explained ( $\mathrm{R}$ squared) by each independent linear model is presented in Fig. 4 together with the number of samples used.

Fig. 3: Relative contribution (percentage of $\mathrm{R}$ squared) of climatic, vegetation and edaphic variables in predicting the content of SOC across $\mathrm{pH}$ classes, for (a) complete mineral soil profiles (0-120 cm depth), (b) topsoils (0-30 cm depth), (c) subsoils (30-120 cm depth). The response variance explained by each environmental variable was normalized to sum to $100 \%$. MAP, mean annual precipitation (mm), MAT, mean annual temperature $\left({ }^{\circ} \mathrm{C}\right)$, LAI, leaf area index, clay, percentage of clay (\%), CEC, effective cation exchange capacity (mmolc $\left.\mathrm{kg}^{-1}\right)$.

Fig. 4: (a) Number of samples and (b) total variance explained (R squared) by each independent linear model as presented in Fig. 1. 
Biogeosciences Discuss., https://doi.org/10.5194/bg-2019-33

Manuscript under review for journal Biogeosciences

Discussion started: 18 February 2019

(C) Author(s) 2019. CC BY 4.0 License.

Fig. 1:

\begin{tabular}{|c|c|c|c|c|c|c|c|c|c|c|}
\hline \multicolumn{11}{|c|}{ (a) Complete mineral soil profile $0-120 \mathrm{~cm}$ depth } \\
\hline pH & $<4$ & $4-4.5$ & $4.5-5$ & $5-5.5$ & $5.5-6$ & $6-6.5$ & 6.5-7 & 7-7.5 & $>7.5$ & All $\mathrm{pH}$ \\
\hline MAP & 0.27 & 0.53 & NS & NS & NS & NS & NS & NS & NS & 0.21 \\
\hline MAT & -0.21 & NS & NS & -0.52 & NS & NS & NS & NS & NS & -0.13 \\
\hline LAI & -0.22 & NS & NS & NS & NS & NS & NS & NS & NS & -0.20 \\
\hline Clay & -0.23 & -0.25 & NS & NS & NS & NS & NS & NS & NS & NS \\
\hline CEC & 0.19 & NS & NS & NS & NS & 0.78 & 0.86 & 0.84 & 0.62 & 0.51 \\
\hline \multicolumn{11}{|c|}{ (b) Topsoil $0-30 \mathrm{~cm}$ depth } \\
\hline pH & $<4$ & $4-4.5$ & $4.5-5$ & $5-5.5$ & $5.5-6$ & $6-6.5$ & 6.5-7 & $7-7.5$ & $>7.5$ & All pH \\
\hline MAP & 0.39 & 0.52 & NS & NS & NS & 0.52 & NS & 0.29 & NS & 0.22 \\
\hline MAT & -0.12 & NS & -0.40 & NS & NS & NS & NS & NS & NS & -0.14 \\
\hline LAI & -0.19 & NS & NS & NS & NS & NS & NS & -0.27 & NS & -0.20 \\
\hline Clay & -0.16 & NS & NS & NS & NS & NS & NS & NS & NS & 0.16 \\
\hline CEC & 0.23 & NS & 0.57 & 0.73 & 0.88 & 0.87 & 0.84 & 0.88 & 0.80 & 0.60 \\
\hline \multicolumn{11}{|c|}{ (c) Subsoil $30-120 \mathrm{~cm}$ depth } \\
\hline pH & $<4$ & $4-4.5$ & $4.5-5$ & $5-5.5$ & $5.5-6$ & 6-6.5 & 6.5-7 & 7-7.5 & $>7.5$ & All $\mathrm{pH}$ \\
\hline MAP & NS & 0.42 & 0.43 & NS & NS & NS & NS & 0.29 & 0.21 & 0.21 \\
\hline MAT & -0.45 & NS & NS & NS & NS & NS & NS & NS & NS & $-N S$ \\
\hline LAI & -0.29 & NS & NS & NS & NS & NS & NS & -0.31 & NS & -0.16 \\
\hline Clay & -0.26 & -0.23 & -0.43 & NS & NS & NS & NS & 0.37 & NS & NS \\
\hline CEC & NS & NS & -0.47 & NS & NS & 0.68 & NS & 0.79 & 0.73 & 0.73 \\
\hline
\end{tabular}


Biogeosciences Discuss., https://doi.org/10.5194/bg-2019-33

Manuscript under review for journal Biogeosciences

Discussion started: 18 February 2019

(c) Author(s) 2019. CC BY 4.0 License.

(c) (1)

Fig. 2:
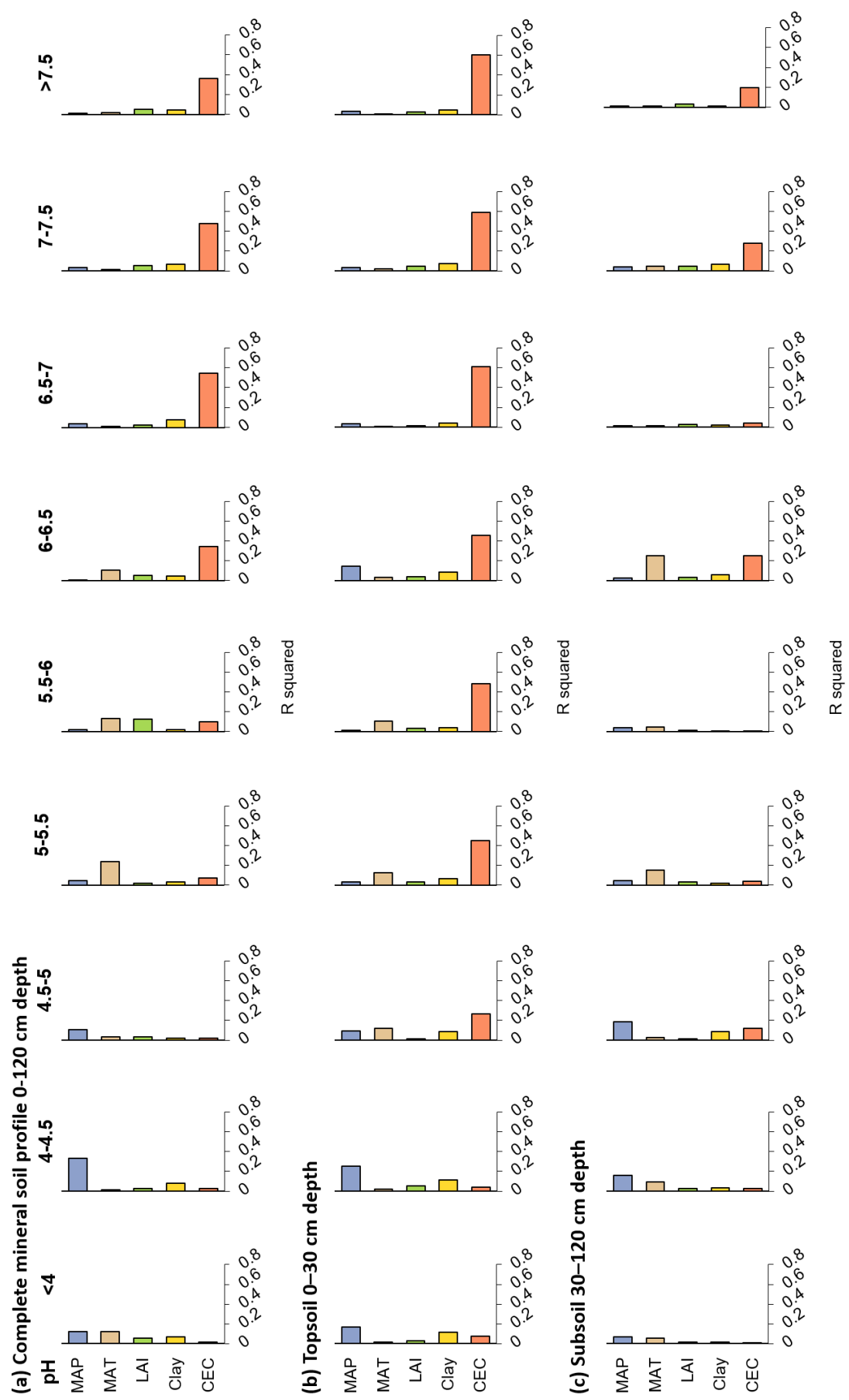
Biogeosciences Discuss., https://doi.org/10.5194/bg-2019-33

Manuscript under review for journal Biogeosciences

Discussion started: 18 February 2019

(c) Author(s) 2019. CC BY 4.0 License.

Fig. 3:

(a)

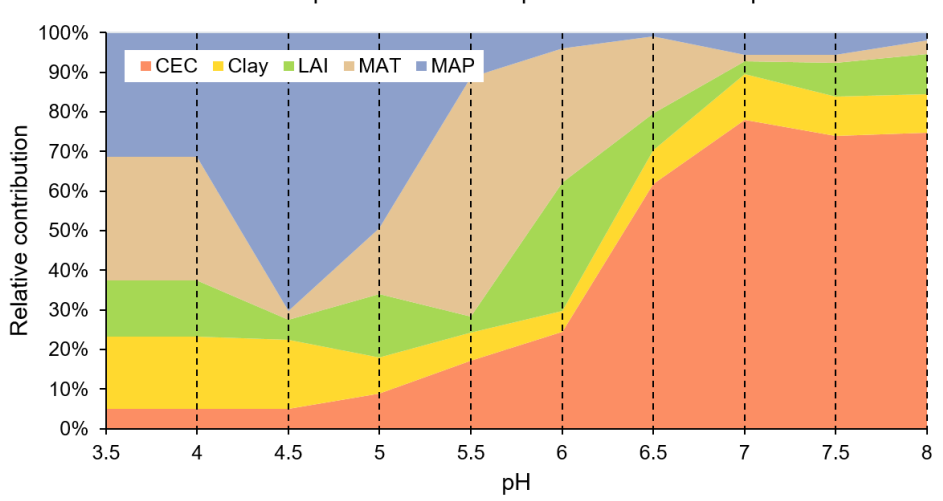

(b) Topsoil 0-30 cm depth

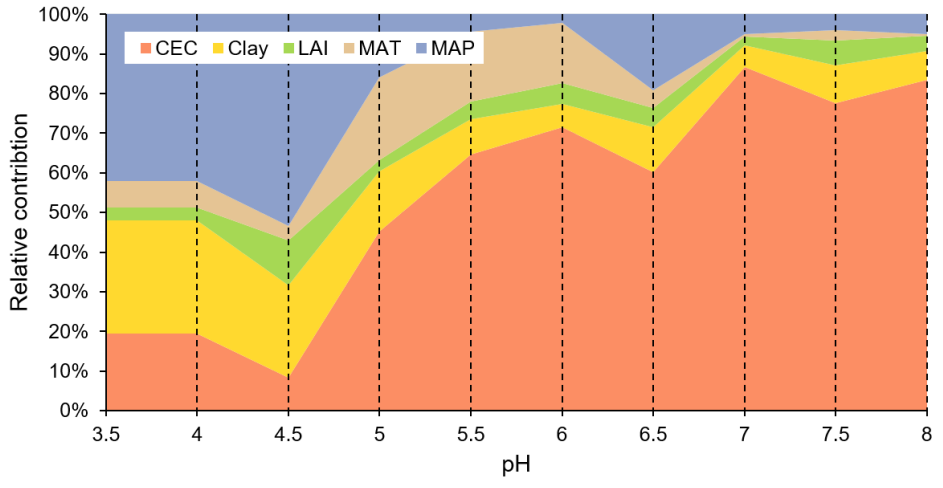

(c) Subsoil 30-120 cm depth

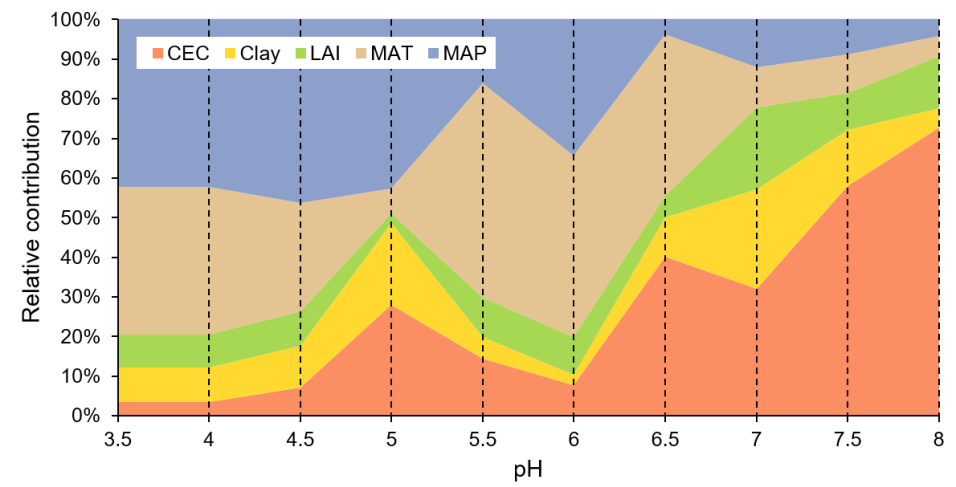


Biogeosciences Discuss., https://doi.org/10.5194/bg-2019-33

Manuscript under review for journal Biogeosciences

Discussion started: 18 February 2019

(c) Author(s) 2019. CC BY 4.0 License.

Fig. 4:
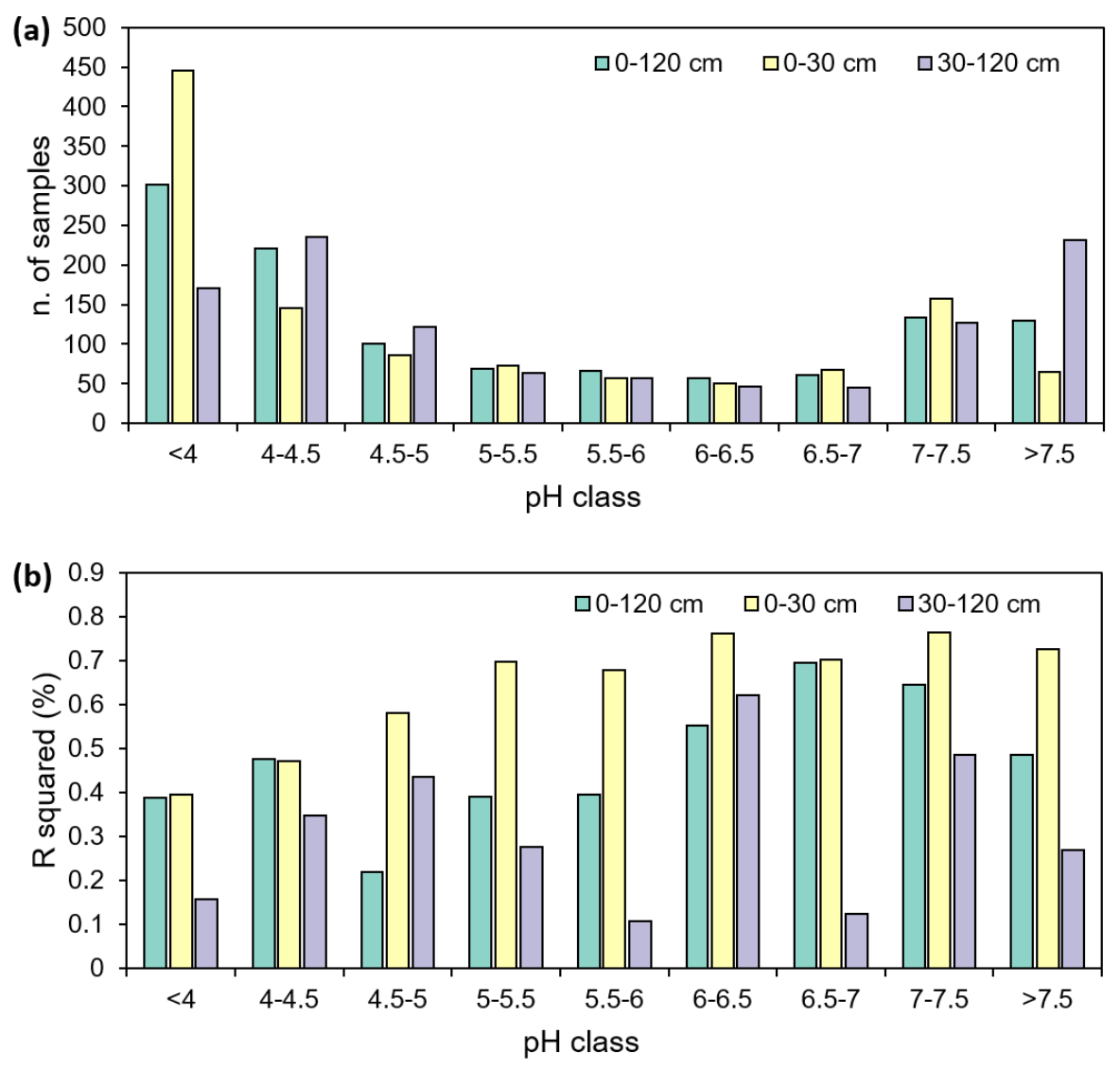
Biogeosciences Discuss., https://doi.org/10.5194/bg-2019-33

Manuscript under review for journal Biogeosciences

Discussion started: 18 February 2019

(c) Author(s) 2019. CC BY 4.0 License.

Table 1: Range of climatic, vegetation and edaphic variables for complete mineral soil profiles (0-120 cm depth), topsoils (0-30 cm depth) and subsoils (30-120 cm depth). MAP, mean annual precipitation; MAT, mean annual temperature; LAI, leaf area index; SOC, soil organic carbon content, CEC eff., effective cation exchange capacity.

\begin{tabular}{|c|c|c|c|}
\hline Soil depth & $0-120 \mathrm{~cm}$ & $0-30 \mathrm{~cm}$ & $30-120 \mathrm{~cm}$ \\
\hline MAP (mm) & \multicolumn{3}{|c|}{$636-2484$} \\
\hline MAT $\left({ }^{\circ} \mathrm{C}\right)$ & \multicolumn{3}{|c|}{$0.1-12.0$} \\
\hline Elevation (m a.s.I.) & \multicolumn{3}{|c|}{$277-2207$} \\
\hline LAI & \multicolumn{3}{|c|}{$2-7.2$} \\
\hline $\operatorname{SOC}\left(\mathrm{g} \mathrm{kg}^{-1}\right)$ & $1.3-376.8$ & $6.0-376.8$ & $0-229.0$ \\
\hline CEC eff. (mmolc $\left.\mathrm{kg}^{-1}\right)$ & $11.4-753.2$ & $20.4-1046.4$ & $6.2-727.9$ \\
\hline Clay (\%) & $1.2-74.7$ & $1.5-74.6$ & $0.8-75.6$ \\
\hline $\mathrm{pH}$ & $3.0-8.0$ & $2.8-8.0$ & $3.0-8.1$ \\
\hline
\end{tabular}


Biogeosciences Discuss., https://doi.org/10.5194/bg-2019-33

Manuscript under review for journal Biogeosciences

Discussion started: 18 February 2019

(C) Author(s) 2019. CC BY 4.0 License.

Table 2: (a) Standardized coefficients indicating explanatory power of climatic, vegetation and edaphic variables in predicting the content of SOC, and (b) amount of variance (\% of R squared) explained by the explanatory variables for complete mineral soil profiles $(0-120 \mathrm{~cm} \mathrm{depth})$, topsoils (0-30 cm depth) and subsoils (30-120 cm depth). The $\mathrm{R}$ squared of metrics is normalized to sum to $100 \%$. MAP, mean annual precipitation; MAT, mean annual temperature; LAI, leaf area index; CEC eff., effective cation exchange capacity; n., number of samples; NS, non significant.

\begin{tabular}{|c|c|c|c|}
\hline & \multicolumn{3}{|c|}{ Complete $\mathrm{pH}$ range } \\
\hline Depth (cm) & $0-120$ & $0-30$ & $30-120$ \\
\hline \multicolumn{4}{|c|}{ (a) Standardized regression coefficients in predicting SOC $\left(\mathrm{g} \mathrm{kg}^{-1}\right)$} \\
\hline $\operatorname{MAP}(\mathrm{mm})$ & 0.31 & 0.30 & 0.26 \\
\hline MAT $\left({ }^{\circ} \mathrm{C}\right)$ & -0.14 & NS & -0.18 \\
\hline LAl & -0.16 & -0.13 & -0.11 \\
\hline Clay (\%) & -0.26 & -0.26 & -0.23 \\
\hline CEC eff. (mmolc kg-1) & 0.48 & 0.66 & 0.32 \\
\hline Rsquared & 0.26 & 0.39 & 0.17 \\
\hline n. & 1138 & 1146 & 1099 \\
\hline \multicolumn{4}{|c|}{ (b) Relative importance (\% of R squared) in predicting SOC $\left(\mathrm{g} \mathrm{kg}^{-1}\right.$ ) } \\
\hline MAP (mm) & 26 & 18 & 31 \\
\hline MAT $\left({ }^{\circ} \mathrm{C}\right)$ & 15 & 4 & 28 \\
\hline LAI & 17 & 9 & 7 \\
\hline Clay (\%) & 7 & 9 & 17 \\
\hline CEC eff. (mmolc $\left.\mathrm{kg}^{-1}\right)$ & 35 & 60 & 17 \\
\hline
\end{tabular}

